\title{
Kwalifikacja obiektu budowlanego jako budynku wchodzącego w skład gospodarstwa rolnego w rozumieniu przepisów o obowiązkowym ubezpieczeniu budynków rolniczych
}

Obowiqzkowym ubezpieczeniem budynku wchodzqcego w skład gospodarstwa rolnego od ognia i innych zdarzeń losowych sq objęte obiekty budowlane spełniajqce kryteria określone przez ustawodawcę. Jednym z nich jest kwalifikacja przedmiotowego obiektu jako budynku w rozumieniu art. 3 pkt 2 ustawy z dnia 7 lipca 1994 roku - Prawo budowlane. Wiqże się to z weryfikacja czterech cech, jakie powinien spełniać każdy budynek: trwałego zwiqzania z gruntem, wydzielenia z przestrzeni za pomoca przegród budowlanych, posiadania fundamentów oraz przykrycia dachem. Rozwój technik budowlanych, a także kreatywność inwestorów, powoduje, że coraz częściej kwalifikacja obiektu budowlanego jako budynku w rozumieniu przepisów przywołanej ustawy budzi watpliwości. W niniejszym artykule - odwołując się w szerokim zakresie do orzecznictwa sqdów administracyjnych oraz pogladów doktryny - dokonano pogłębionej analizy wszystkich wskazanych cech budynku. Wskazano również przesłanki objęcia obiektu budowlanego obowiqzkowym ubezpieczeniem budynku wchodzq̨cego w skład gospodarstwa rolnego od ognia i innych zdarzeń losowych.

Słowa kluczowe: obowiązkowe ubezpieczenie budynku rolniczego od ognia i innych zdarzeń losowych, budynek rolniczy, przesłanki objęcia obiektu budowlanego obowiązkowym ubezpieczeniem budynku rolniczego, budynek, cechy budynku.

\section{Wstęp}

Zgodnie z rozwiązaniem przyjętym przez ustawodawcę zasada jest, że budynki rolnicze podlegają obowiązkowemu ubezpieczeniu w trybie przepisów ustawy z dnia 22 maja 2003 roku o ubezpieczeniach obowiązkowych, Ubezpieczeniowym Funduszu Gwarancyjnym i Polskim Biurze 
Ubezpieczycieli Komunikacyjnych ${ }^{1}$. Rolnik jest bowiem obowiązany zawrzeć umowę ubezpieczenia budynku wchodzącego w skład gospodarstwa rolnego od ognia i innych zdarzeń losowych², przy czym obowiązek ten nie obejmuje wszystkich obiektów budowlanych ${ }^{3}$. Dotyczy on bowiem wyłącznie obiektów budowlanych, które spełniajał łącznie przesłanki pozytywne objęcia zakresem przedmiotowego ubezpieczenia rolniczego, a jednocześnie nie podlegają wyłączeniu na skutek ziszczenia się jednej z przesłanek negatywnych.

Mając zatem na uwadze, że nie każdy obiekt budowlany wchodzący w skład gospodarstwa rolnego wpisuje się w zakres przedmiotowy obligatoryjnego ubezpieczenia budynku rolniczego, za niezbędną należy uznać pogłębioną analizę w tym zakresie. W tym celu konieczne jest badanie w szczególności uregulowań mających zastosowanie przy definiowaniu obiektu budowlanego jako budynku wchodzącego w skład gospodarstwa rolnego, jak i przepisów normujących legalne przeprowadzenie rozbiórki obiektu budowlanego. Z uwagi na ograniczenia objętościowe niniejszego tekstu, jego przedmiot koncentruje się na analizie pierwszej grupy przepisów, a - w zwiazku z pojawiającymi się wątpliwościami interpretacyjnymi - przede wszystkim na tych, na podstawie których następuje kwalifikacja obiektu jako budynku w rozumieniu przepisów ustawy z dnia $?$ lipca 1994 roku - Prawo budowlane ${ }^{4}$. Z uwagi bowiem na rozwój technik budowlanych, a także kreatywność inwestorów, prawidłowa kwalifikacja obiektu jako budynku w rozumieniu przepisów p.b. coraz częściej budzi wątpliwości.

Zaznaczenia wymaga przy tym, że celem niniejszego artykułu nie jest udzielenie odpowiedzi na pytanie, czy zakład ubezpieczeń jest zobligowany do weryfikowania przesłanek determinujacych kwalifikację obiektu budowlanego jako budynku rolniczego, czy też może opierać się na wskazaniu ubezpieczającego w tym zakresie. Poza zakresem rozważań pozostają również konsekwencje zawarcia umowy obowiązkowego ubezpieczenia budynku rolniczego w odniesieniu do obiektu, który nie może być kwalifikowany jako budynek rolniczy, w tym w szczególności w zakresie ewentualnej nieważności takiej umowy czy przyjęcia, iż zawarto umowę ubezpieczenia dobrowolnego.

\section{Przesłanki objęcia obowiązkowym ubezpieczeniem budynku rolniczego}

Obowiazkowym ubezpieczeniem od ognia i innych zdarzeń losowych objęte są budynki wchodzące w skład gospodarstwa rolnego ${ }^{5}$, czyli - jak wskazano w definicji ujętej w art. 2 ust. 1 pkt 2 u.u.o. - obiekty budowlane o powierzchni powyżej $20 \mathrm{~m}^{2}$ określone w art. 3 pkt 2 p.b., będace w posiadaniu rolnika. Oznacza to, iż obiekt budowlany może być sklasyfikowany jako budynek rolniczy wówczas, gdy zachodzą łącznie trzy przesłanki wskazane w przywołanym powyżej przepisie. Jednocześnie ustawodawca wskazał przesłanki negatywne objęcia obowiązkowym ubezpieczeniem budynku wchodzącego w skład gospodarstwa rolnego. Nie są bowiem objęte przedmiotowym

1. Dz.U. 2021, poz. 854 z późn. zm. (w dalszej części przywoływana jako u.u.o.).

2. Zob. art. 59 u.u.o.

3. Zob. art. 72 u.u.o.

4. Dz. U. 2020, poz. 1333 z późn. zm. (dalej: p.b.).

5. Zob. art. 4 pkt 3 u.u.o. 
ubezpieczeniem budynki, których stan techniczny osiagnałł $100 \%$ normy zużycia, oraz budynki przeznaczone do rozbiórki na podstawie ostatecznych decyzji właściwych organów ${ }^{6}$.

Mając na uwadze powyższe, wskazać należy, że konkretny obiekt budowlany jest budynkiem rolniczym tylko wówczas, gdy spełnia wszystkie cechy budynku, o których mowa wart. art. 3 pkt 2 p.b., czyli jest trwale związany z gruntem, wydzielony z przestrzeni za pomoca przegród budowlanych oraz posiada fundamenty i dach. Ponieważ weryfikacja tych cech w odniesieniu do poszczególnych obiektów może budzić wạtpliwości, zostały one poddane szczegółowej analizie w kolejnych częściach niniejszego artykułu.

Powierzchnia budynku kwalifikowanego jako rolniczy - jak już wskazano powyżej - nie może być mniejsza niż $20 \mathrm{~m}^{2}$. Zauważenia wymaga przy tym, iż ustawodawca nie wskazał kryteriów, jakie należy stosować przy określaniu tej powierzchni. Przyjać należy jednak, iż właściwa w tym zakresie nie będzie powierzchnia całkowita budynku. Można natomiast podnosić zarówno argumenty za stosowaniem w tym zakresie powierzchni budynku netto, jak i jego powierzchni użytkowej? Rozważania te zasadniczo nie maja jednak istotnego znaczenia, gdyż zdecydowana większość budynków rolniczych to - bez względu na sposób liczenia - budynki o dużo większej powierzchni.

Ustawodawca wymaga nadto, aby budynek rolniczy znajdował się w posiadaniu rolnika, czyli osoby fizycznej, w której posiadaniu lub współposiadaniu jest gospodarstwo rolne ${ }^{9}$. Definiując rolnika, trzeba odwołać się do brzmienia art. 2 ust. 1 pkt 4 u.u.o., zgodnie z którym pod pojęciem gospodarstwa rolnego należy rozumieć obszar użytków rolnych, gruntów pod stawami oraz skla-

6. Zob. art. 72 pkt 1 i 2 u.u.o. Zaznaczyć należy, iż z regulacji art. 72 pkt 3 u.u.o. wynika, iż nie są objęte ubezpieczeniem w gospodarstwach rolnych namioty i tunele foliowe, przy czym regulację tę należy uznać za zbędna z uwagi na okoliczność, iż namioty i tunele foliowe nie spełniają przynajmniej jednej z wymienionych przesłanek pozytywnych, a zatem nie są budynkiem w rozumieniu art. 3 pkt 2 p.b.

7. Zaznaczyć trzeba przy tym, że w przepisach p.b. nie zdefiniowano powierzchni użytkowej budynku ani nie wskazano sposobu jej liczenia. Definicja tego pojęcia pojawia się natomiast w innych ustawach, przy czym nie jest ono definiowane w tożsamy sposób. I tak np. zgodnie z art. 1a ust. 1 pkt 5 ustawy z dnia 12 stycznia 1991 r. o podatkach i opłatach lokalnych (Dz. U. 2019, poz. 1170 z późn zm.) przez powierzchnię użytkową budynku lub jego części należy rozumieć powierzchnię mierzoną po wewnętrznej długości ścian na wszystkich kondygnacjach, z wyjatkiem powierzchni klatek schodowych oraz szybów dźwigowych; za kondygnację uważa się również garaże podziemne, piwnice, sutereny i poddasza użytkowe. Natomiast - jak wskazano w art. 16 ust. 4 ustawy z dnia 28 lipca 1983 r. o podatku od spadków i darowizn (Dz. U. 2021, poz. 1043 z późn. zm.) - za powierzchnię użytkową budynku (lokalu) w rozumieniu ustawy uważa się powierzchnię mierzoną po wewnętrznej długości ścian pomieszczeń na wszystkich kondygnacjach (podziemnych i naziemnych, z wyjątkiem powierzchni piwnic i klatek schodowych oraz szybów dźwigów). Zgodnie zaś z regulacją art. 2 ust. 1 pkt 7 ustawy z dnia 21 czerwca 2001 r. o ochronie praw lokatorów, mieszkaniowym zasobie gminy i o zmianie Kodeksu cywilnego (Dz. U. 2020, poz. 611 z późn. zm.) powierzchnią użytkową lokalu jest powierzchnia wszystkich pomieszczeń znajdujących się w lokalu, a w szczególności pokoi, kuchni, spiżarni, przedpokoi, alków, holi, korytarzy, łazienek oraz innych pomieszczeń służących mieszkalnym i gospodarczym potrzebom lokatora, bez względu na ich przeznaczenie i sposób używania; za powierzchnię użytkową lokalu nie uważa się powierzchni balkonów, tarasów i loggii, antresoli, szaf i schowków w ścianach, pralni, suszarni, wózkowni, strychów, piwnic i komórek przeznaczonych do przechowywania opału.

8. W literaturze wskazuje się nawet, iż „powierzchnia budynku nie wymaga wyjaśnienia” ( tak J. Nawracała, [w:] Komentarz do ustawy o ubezpieczeniach obowiqzkowych, Ubezpieczeniowym Funduszu Gwarancyjnym i Polskim Biurze Ubezpieczycieli Komunikacyjnych, Tom I, [red.] Z. Brodecki, M. Serwach, M. Glicz, Wolters Kluwer, Warszawa 2010, art. 59, LEX/el.). Por. też J. Nawracała, [w:] [red.] Kontrakty na rynku ubezpieczeń. Komentarz do przepisów i warunków ubezpieczeń, D. Fuchs, K. Malinowska, D. Maśniak, Wolters Kluwer, Warszawa 2020, s. 736.

9. Zob. art. 2 ust. 1 pkt 12 u.u.o. 
syfikowanych jako użytki rolne gruntów pod zabudowaniami, przekraczający łącznie powierzchnię 1,0 ha, jeżeli podlega on w całości lub części opodatkowaniu podatkiem rolnym, a także obszar takich użytków i gruntów, niezależnie od jego powierzchni, jeżeli jest prowadzona na nim produkcja rolna, stanowiąca dział specjalny w rozumieniu przepisów o podatku dochodowym od osób fizycznych. Z powyższego wywodzi się, że przedmiotowy obowiązek ubezpieczenia obejmuje zarówno budynki znajdujące się w posiadaniu samoistnym rolnika, jak i w posiadaniu zależnym ${ }^{10}$. Wydaje się, iż sfomułowanie użyte przez ustawodawcę nie powinno budzić wątpliwości, iż obowiązek ten obejmuje wyłącznie budynki wchodzące w skład gospodarstwa rolnego, a nie wszystkie będące w posiadaniu rolnika, jak np. dom letniskowy czy mieszkanie w mieście ${ }^{11}$.

Odnosząc się zaś do przesłanek negatywnych objęcia obowiązkowym ubezpieczeniem budynku wchodzaccego w skład gospodarstwa rolnego od ognia i innych zdarzeń losowych, wskazać należy, że zużycie stanu technicznego wyłączonych z zakresu przedmiotowego ubezpieczenia budynków zależy głównie od ich wieku. Analizy wymaga natomiast kolejna z przesłanek negatywnych, zgodnie z którą wyłączone z zakresu ubezpieczenia zostały budynki przeznaczone do rozbiórki na podstawie ostatecznych decyzji właściwych organów. Zasada jest bowiem, że roboty budowlane, w tym również roboty rozbiórkowe ${ }^{12}$, można rozpocząć jedynie na podstawie decyzji budowlanej ${ }^{13}$. Oznacza to, że roboty budowlane polegające na rozbiórce zasadniczo moga być prowadzone w oparciu o decyzję uprawniająca w tym zakresie ${ }^{14}$. Decyzją taką - wydawana wyłacznie w przypadku, gdy właściciel obiektu wyraża chęć na jego rozbiórkę ${ }^{15}$ - jest pozwolenie na rozbiórkę. Ustawodawca wprowadził jednak odstępstwa od tej zasady, wskazując obiekty budowlane, których rozbiórka nie wymaga stosownego pozwolenia. W aktualnym stanie normatywnym możliwe jest bowiem legalne dokonanie - zbieżnej z oczekiwaniami właściciela - rozbiórki obiektu budowlanego albo na podstawie pozwolenia na rozbiórkę, albo po skutecznym dokonaniu w trybie uproszczonym zgłoszenia rozbiórki właściwemu organowi administracji architektoniczno-budowlanej, albo wreszcie bez uruchamiania żadnego trybu administracyjnoprawnego. Nadto przepisy dopuszczają wydanie decyzji nakazującej rozbiórkę obiektu budowlanego ${ }^{16}$.

10. Zob. J. Nawracała, [w: KomentarzE, art. 59, LEX/el. Por. też J. Nawracała, [w:] KontraktyE, s. 737.

11. Por. J. Nawracała, [w:] KomentarzE, art. 59, LEX/el. Por. też J. Nawracała, [w:] KontraktyE, s. 737-738.

12. Pod pojęciem robót budowlanych należy rozumieć bowiem - jak wskazano $w$ art. 3 pkt $?$ p.b. - budowę, a także prace polegające na przebudowie, montażu, remoncie lub rozbiórce obiektu budowlanego (na ten temat zob. też: A. Despot-Młodanowicz, [w:] Prawo budowlane. Komentarz, [red.] A. Plucińska-Filipowicz, M. Wierzbowski, Wolters Kluwer, Warszawa 2021, art. 3/LEX/el.).

13. Zob. art. 28 ust. 1 p.b.

14. Por. wyrok NSA z dnia 16 września 2011 r., sygn. II OSK 1366/10, LEX nr 1151853; wyrok WSA w Krakowie z dnia 22 września 2017 r., sygn. II SA/Kr 639/17, LEX nr 2387382.

15. Do wniosku o pozwolenie na budowę - jak wskazano w art. $30 \mathrm{~b}$ ust. 3 pkt 1 p.b. - konieczne jest bowiem dołączenie zgody właściciela obiektu budowlanego na jego rozbiórkę lub jej kopii.

16. Z uwagi na obszerność problematyki aktów odnoszących się do rozbiórki obiektu budowlanego, została ona wyłączona z niniejszego opracowania (na ten temat zob. np.: K. Małysa-Sulińska, Administracyjnoprawne aspekty inwestycji budowlanych, Wolters Kluwer, Warszawa 2012, s. 288 i nast.; A. Gliniecki, A. Ostrowska, [w:] Prawo budowlane. Komentarz, [red.] A. Gliniecki, Lexis Nexis, Warszawa 2014, s. 231 i nast.; A. Kosicki, [w: Prawo budowlane. Komentarz, [red.] A. Plucińska-Filipowicz, M. Wierzbowski, art. 28 i n./LEX/el.]. 


\section{Definicja budynku ujęta w ustawie - Prawo budowlane}

Zgodnie z przywołanym już powyżej art. 3 pkt 2 p.b. pod pojęciem budynku należy rozumieć obiekt budowlany, który jest trwale związany z gruntem, wydzielony z przestrzeni za pomoca przegród budowlanych oraz posiada fundamenty i dach. Zaznaczenia wymaga przy tym, że ustawodawca wśród obiektów budowlanych ${ }^{17}$ wyróżnia - poza budynkami - budowle ${ }^{18}$ oraz obiekty małej architektury ${ }^{19}$, przy czym obie te kategorie z uwagi na brzmienie omawianych regulacji nie podlegaja obowiązkowi obligatoryjnego ubezpieczenia rolniczego. W związku z powyższym - jak podkreśla się to w orzecznictwie sądowoadministracyjnym - budynkiem nie jest każdy obiekt budowlany, a wyłącznie taki, który spełnia łącznie wskazane powyżej przesłanki ujęte w art. 3 pkt 2 p.b. ${ }^{20}$

Nie odpowiada zatem określonym w przepisie warunkom obiekt budowlany wykonany bez przegród budowlanych, fundamentów bądź bez dachu lub niezwiązany trwale z gruntem, a w związku z tym nie może być uznawany za budynek ${ }^{21}$. Jednocześnie w orzecznictwie sądowoadministracyjnym podnosi się, że spełniajacy te przesłanki obiekt pozostaje budynkiem nawet wówczas, gdy ze względów technicznych, prawnych bądź faktycznych nie może być wykorzystywany zgodnie z przeznaczeniem. Braki w wyposażeniu budynku, częściowy ich demontaż czy ogólna dewastacja bądź też jego niewykorzystywanie nie powodują bowiem utraty przez taki obiekt cech budynku²2.

\section{Trwałe związanie obiektu z gruntem}

0 trwałym związaniu obiektu z gruntem przesądza jego konstrukcja techniczna, a związanie to ma charakter powiązania w sensie fizycznym, a nie wyłącznie gospodarczym ${ }^{23}$. Cecha trwałego związania z gruntem sprowadza się zatem do posadowienia obiektu w taki sposób, by zapewnić mu stabilność i możliwość przeciwdziałania czynnikom zewnętrznym, jakimi są siły przyrody, które mogłyby go zniszczyć lub spowodować jego przemieszczenie lub przesunięcie na inne miejsce. Trwałe połączenie z gruntem nie ma zatem na celu przeciwdziałania działalności człowieka ${ }^{24}$. Oznacza

17. Definicja obiektu budowlanego została ujęta w art. 3 pkt 1 p.b., zgodnie z którym pod pojęciem tym należy rozumieć budynek, budowlę bądź obiekt małej architektury, wraz z instalacjami zapewniającymi możliwość użytkowania obiektu zgodnie z jego przeznaczeniem, wzniesiony z użyciem wyrobów budowlanych (na ten temat zob. np. A. Despot-Mładanowicz, [w:] Prawo budowlane. Komentarz, [red.] A. Plucińska-Filipowicz, M. Wierzbowski, art. 3/LEX/el.].

18. Definicja budowli została ujęta w art. 3 pkt 3 p.b. (na ten temat zob. np. ibidem).

19. Obiekt małej architektury został zaś zdefiniowany w art. 3 pkt 4 p.b. (na ten temat zob. np. ibidem).

20. Zob. wyrok NSA z dnia 3 kwietnia 2019 r., sygn. II OSK 1465/17, LEX nr 2650588.

21. Zob. wyrok NSA z dnia 28 listopada 2019 r., sygn. II OSK 131/18, LEX nr 3065814. Por. też: wyrok NSA z dnia 18 września 2019 r., sygn. II OSK 2507/17, LEX nr 3073340; wyrok WSA w Krakowie z dnia 21 grudnia 2018 r., sygn. II SA/Kr 1221/18, LEX nr 2603723.

22. Zob. wyrok WSA w Lublinie z dnia 11 października 2019 r., sygn. I SA/Lu 244/19, LEX nr 2731351.

23. Por. T. Asman, Z. Niewiadomski, [w: Prawo budowlane. Komentarz, [red.] Z. Niewiadomski, CH Beck, Warszawa 2011, s. 42.

24. Zob.: wyrok NSA z dnia 18 maja 2020 r., sygn. I OSK 1579/19, LEX nr 3020838; wyrok NSA z dnia 24 września 2019 r., sygn. II OSK 2447/18, LEX nr 2751289; wyrok NSA z dnia 28 kwietnia 2020 r., sygn. II OSK 1899/19, LEX nr 3085281; wyrok WSA w Olsztynie z dnia 4 marca 2021 r., sygn. II SA/0I 679/20, LEX nr 3150384; wyrok WSA 
to, że - jak wskazuje się w orzecznictwie sądowoadministracyjnym - np. kontener posadowiony na bloczkach betonowych ułożonych bezpośrednio na gruncie, z uwagi na brak trwałego związania z tym gruntem, nie może być kwalifikowany jako budynek, o którym mowa w art. 3 pkt 2 p.b. ${ }^{25}$

W miejscu tym zauważyć należy, że związanie obiektu z gruntem często rozumie się w ten sposób, iż ma on fundamenty, choć - jak wskazuje Sąd Najwyższy - nie jest to reguła bezwzględna, a trwałości tego zespolenia nie przekreśla zależność od woli właściciela nieruchomości sạsiedniej ${ }^{26}$. Podkreślić należy przy tym, iż dla przyjęcia trwałego związania z gruntem rozstrzygające jest to, w jaki sposób obiekt opiera się czynnikom, które mogą spowodować jego zniszczenie lub przesunięcie. 0 trwałości tego związania decyduje zatem jego intensywność, co może mieć miejsce nie tylko wtedy, gdy obiekt jest połączony z fundamentem w całości zagłębionym w gruncie, ale także gdy wielkość, masa i względy bezpieczeństwa, w tym opieranie się oddziaływaniom atmosferycznym wskazują na trwałość jego posadowienia. Obiekty trwale związane z gruntem są bowiem odporne w sposób zapewniający im stabilność na działanie warunków atmosferycznych, w tym np. podmuchów wiatru. Na potrzeby weryfikacji tej cechy obiektu budowlanego nie ma zatem znaczenia okoliczność, czy posiada on fundamenty oraz w jakim zakresie jest zagłębiony w gruncie. Jednocześnie zaznacza się, iż taki obiekt - jeśli nie posiada fundamentów - nie może być zakwalifikowany do kategorii budynków²?.

\section{Posiadanie przez obiekt fundamentu}

Zgodnie bowiem z definicją ujętą w art. 3 pkt 2 p.b. obiekt będący budynkiem musi posiadać fundamenty. Przepisy p.b. nie zawierają definicji fundamentu, a nadto nie odsyłają do żadnego innego aktu ustawowego zawierającego przedmiotową definicję. Określając cechy charakteryzujące fundament, trzeba zatem posiłkować się zakresem semantycznym tego pojęcia w języku potocznym. Fundament należy więc postrzegać jako osadzoną w gruncie dolną część obiektu, przy

w Gdańsku z dnia 20 stycznia 2021 r., sygn. II SA/Gd 415/20, LEX nr 3146074; wyrok WSA w Gdańsku z dnia 8 lipca 2020 r., sygn. II SA/Gd 647/19, LEX nr 3029072.

25. Zob. wyrok WSA w Gliwicach z dnia 28 kwietnia 2021 r., sygn. I SA/GI 38/21, LEX nr 3188333; wyrok WSA w Gliwicach z dnia 21 września 2018 r., sygn. II SA/GI 565/18, LEX nr 2556311. Należy jednak zwrócić uwagę na wyrok NSA z dnia 24 września 2019 r., sygn. II OSK 2447/18, LEX nr 2751289, w którym wskazano, że „obiekt ten składa się z przyczepy kempingowej typu holenderskiego, która jest posadowiona na betonowym utwardzeniu i oprócz kół jest wsparta na betonowych bloczkach. Przyczepa jest pokryta konstrukcją dachową, która umieszczona jest słupach wykonanych z desek, powiązanych z przyczepą za pomocą kątowników. Bez wątpienia więc obiekt ten posiada dach. Fundament jest elementem konstrukcyjnym budynku, którego zadaniem jest przenoszenie obciążeń na grunt. Fundamentem tego obiektu jest betonowe utwardzenie, na którym stoja bloczki betonowe wspierające przyczepę. Betonowe utwardzenie przenosi obciążenie z obiektu na grunt i zapobiega jego osiadaniu na gruncie oraz pełni funkcję niwelującą zmienny poziom terenu”, a nadto „techniczna możliwość usunięcia betonowych bloczków i przemieszczenia przyczepy razem z dachem w inne miejsce nie przesądza jednak o braku trwałego związania tego obiektu z gruntem".

26. Zob. postanowienie SN z dnia 26 listopada 2019 r., sygn. IV CSK 418/18, LEX nr 2784013.

27. Zob. wyrok NSA z dnia 28 kwietnia 2020 r., sygn. II OSK 1899/19, LEX nr 3085281. Por. też wyrok NSA z dnia 10 kwietnia 2019 r., sygn. II OSK 1327/17, LEX nr 2681541. Por. też wyrok WSA w Lublinie z dnia 19 września 2019 r., sygn. II SA/Lu 118/19, LEX nr 274300 ? 
czym rodzaje fundamentów mogą być różne, a to np. stopowe, ławowe, płytowe ${ }^{28}$. W orzecznictwie sądowoadministracyjnym podnosi się nadto, że dolna płaszczyzna fundamentu musi znajdować się pod powierzchnią ziemi, zaś jego przeniesienie w inne miejsce musi wymagać prac ziemnych. Wskazuje się jednocześnie, że fundament jest elementem konstrukcyjnym budynku, który zapewnia jego stabilność i trwałość oraz przenosi ciężar budynku na grunt. W związku z tym punktowo ułożone na ziemi betonowe bloczki - nie spełniając takiej roli - nie są fundamentem ${ }^{29}$. Fundament budynku spełniający te wymagania może być wykonany z różnych materiałów budowlanych i z zastosowaniem różnych technologii, gdyż technologia fundamentu nie zmienia charakteru obiektu budowlanego jako budynku ${ }^{30}$.

Zauważenia wymaga również, że posiadanie przez budynki wspólnego fundamentu nie stanowi przeszkody, aby uznać, że każdy z obiektów stanowi samodzielny budynek. Okoliczność, że kilka obiektów jest posadowionych na wspólnej płycie fundamentowej, nie przesądza o tym, że jest to jeden budynek. Oznacza to, że kilka budynków może mieć jeden wspólny fundament, a to dlatego, że - jak wskazuje się w orzecznictwie sądowoadministracyjnym - istotne znaczenie ma zabudowa powyżej powierzchni ziemi, a nie jej części podziemne ${ }^{31}$.

\section{Wydzielenie obiektu z przestrzeni za pomocą przegród budowlanych}

Kolejną przesłanką determinującą kwalifikację obiektu budowlanego jako budynku jest wydzielenie go z przestrzeni za pomocą przegród budowlanych. W orzecznictwie wskazuje się, że w określeniu tym zawierają się dwie cechy, a to: obiekt jest wydzielony z przestrzeni, a wydzielenie to następuję za pomoca przegrody budowlanej. Funkcja przegrody budowlanej jest wyodrębnienie obiektu z przestrzeni zewnętrznej w taki sposób, aby możliwe było wskazanie przestrzeni przypisanej do obiektu ${ }^{32}$. Obiekt może być zaś wyodrębniony z przestrzeni zewnętrznej ścianami trwałymi, czyli wykonanymi z trwałych, solidnych materiałów, przy czym kryteriów takich nie spełniaja przegrody pełniące funkcję prowizoryczną, w szczególności wykonane z materiałów niegwarantujących trwałości, jak np. płótno, cienka dykta czy folia ${ }^{33}$. Jednocześnie zauważenia wymaga, że - z uwagi na ciagły rozwój technik budowlanych - pojęcia trwałej ściany nie można

28. Zob. wyrok WSA w Szczecinie z dnia 15 października 2020 r., sygn. II SA/Sz 151/20, LEX nr 3088369. Zob. też hasło fundament w Encyklopedii PWN, w którym wskazano, że fundamentem jest „najniżej położony element konstrukcyjny obiektu budowlanego przenoszący oddziaływanie (obciążenia) konstrukcji nośnej na podłoże gruntowe", https://encyklopedia.pwn.pl/szukaj/fundament.html [dostęp: ?.08.2021].

29. Zob. wyrok WSA w Szczecinie z dnia 15 października 2020 r., sygn. II SA/Sz 151/20, LEX nr 3088369. Zauważenia wymaga jednak, że w orzecznictwie sądowoadministracyjnym prezentowany jest również pogląd odmienny, zgodnie z którym bloczki betonowe mogą tworzyć fundament (zob. wyrok NSA z dnia 10 kwietnia 2019 r., sygn. II OSK 1499/17, LEX nr 2650604).

30. Zob. wyrok WSA w Kielcach z dnia 3 lipca 2020 r., sygn. II SA/Ke 917/19, LEX nr 3040524. Por. też wyrok WSA w Gdańsku z dnia 20 stycznia 2021 r., sygn. II SA/Gd 415/20, LEX nr 3146074.

31. Zob. wyrok NSA z dnia 4 września 2019 r., sygn. II OSK 56/18, LEX nr 2751907.

32. Zob. wyrok WSA z dnia 5 listopada 2019 r., sygn. I SA/GI 114/19, LEX nr 2743326.

33. Zob. wyrok WSA w Gdańsku z dnia 11 grudnia 2008 r., sygn. III SA/Gd 213/08, LEX nr 477247. Podobne stanowisko przyjmuje się w odniesieniu do przegród budowlanych wydzielających samodzielny lokal (por. K. Małysa-Sulińska, Przesłanki wydania zaświadczenia o samodzielności lokalu wykorzystywanego zgodnie z przeznaczeniem na cele inne niż mieszkalne, „Casus” 2020, nr 98/99, s. 27]). 
utożsamiać wyłącznie z przegrodą murowaną, gdyż aktualnie budynki są wykonywane nie tylko z tradycyjnych materiałów budowlanych, co oznacza możliwość wyodrębnienia budynku z przestrzeni zewnętrznej, np. ścianą ze stali ocynkowanej ${ }^{34}$.

Zauważa się również, że przegrody te powinny być przynależne do konkretnego obiektu, który w związku z tym jest konstrukcyjnie samodzielny. Rozbiórka takiego obiektu, nawet gdy przylega on do innego budynku, musi być bowiem możliwa bez zagrożenia dla konstrukcji tego ostatniego ${ }^{35}$.

Jednocześnie podkreślenia wymaga, że posiadanie przez obiekt ścian z otworami nie jest jednoznaczne z tym, że nie jest on wyodrębniony z przestrzeni. Ściana nie traci bowiem swojej funkcji wyodrębniającej budynek z przestrzeni zewnętrznej przez to, że posiada otwory ${ }^{36}$. Brak jest również uzasadnienia dla przyjęcia, że ściana obiektu, w której wykonano otwór drzwiowy lub okienny, ale nie zamontowano drzwi lub okna, nie stanowi przegrody budowlanej, o której mowa w art. 3 pkt 2 p.b. Niezamontowanie tych elementów w ścianie zewnętrznej obiektu nie powoduje zmiany funkcji ściany, która wyodrębnia budynek z przestrzeni zewnętrznej ${ }^{37}$. Należy bowiem odróżnić budynek od np. wiaty, która - co do zasady - pozbawiona jest wszystkich albo większości przegród zewnętrznych ${ }^{38}$.

\section{Posiadanie przez obiekt dachu}

$Z$ definicji ujętej w art. 3 pkt 2 p.b. wynika nadto, że obiekt będący budynkiem musi posiadać dach, przy czym przepisy p.b. nie zawierają definicji tego pojęcia ani nie odsyłają do takiej definicji zawartej w innym akcie normatywnym. W języku potocznym dach oznacza część konstrukcji budynku ograniczająca go od góry, która zabezpiecza przed opadami atmosferycznymi, wiatrem, promieniowaniem ultrafioletowym, hałasem oraz stratami ciepła ${ }^{39}$ i znaczeniem tego pojęcia należy posiłkować się, określając charakterystyczne cechy dachu. Z uwagi na kształt wyróżnia się

34. Por. wyrok NSA z dnia 19 października 2017 r., sygn. I OSK 3267/15, LEX nr 2404349.

35. Zob. wyrok WSA w Gliwicach z dnia 19 listopada 2020 r., sygn. II SA/GI 570/20, LEX nr 3098102, w którym zdefiniowano budynek mieszkalny jednorodzinny w zabudowie bliźniaczej, wskazując, że „cechą zabudowy bliźniaczej jest wydzielenie z przestrzeni za pomocą przegród budowlanych dwóch budynków. Muszą to być obiekty konstrukcyjnie samodzielne, tak aby możliwa była rozbiórka jednego obiektu (wszystkich ścian) bez zagrożenia dla konstrukcji drugiego. Oba budynki muszą mieć zatem samodzielne przegrody budowlane, które jednak do siebie przylegaja, gdyż są dobudowane. Nie jest przy tym wymagane istnienie przegrody dylatacyjnej. Chodzi jedynie o to, aby wykonano ściany w każdym z budynków. Jeżeli budynek ma odrębne wejścia, lecz wspólną ścianę, nie stanowi obiektu w zabudowie bliźniaczej. Zabudowa bliźniacza charakteryzuje się zatem tym, że dwa samodzielne konstrukcyjnie obiekty przylegają do siebie własnymi ścianami”.

36. Zob. wyrok WSA w Poznaniu z dnia 17 lipca 2019 r., sygn. II SA/Po 255/19, LEX nr 2700461.

37. Zob. wyrok WSA w Rzeszowie z dnia 12 lutego 2020 r., sygn. II SA/Rz 1400/19, LEX nr LEX nr 303417?.

38. Zob. wyrok WSA w Gdańsku z dnia 19 lutego 2020 r., sygn. II SA/Gd 389/19, LEX nr 2939060. Zob. też wyrok NSA z dnia 17 marca 2020 r., sygn. II OSK 603/19, LEX nr 3038270, w którym wskazano, że wiata definiowana jest w każdym przypadku jako lekka konstrukcja, która nawet jeśli będzie posiadała ściany (np. w celu ochrony przed czynnikami atmosferycznymi takimi jak wiatr], to nie będzie mieścić się w kategorii budynku. Por. też: wyrok NSA z dnia 9 stycznia 2019 r., sygn. II OSK 3465/18, LEX nr 2604876; wyrok WSA w Poznaniu z dnia 2 października 2019 r., sygn. IV SA/Po 392/19, LEX nr 2733093.

39. Zob. Encyklopedia PWN, https://encyklopedia.pwn.pl/szukaj/dach.html [dostęp: 7.08.2021]. Por. też Słownik języka polskiego, PWN, Warszawa 2007, s. 29?. 
różne rodzaje dachu, a to np.: pulpitowy, jednospadowy, dwuspadowy, czterospadowy, naczółkowy, kopulasty, mansardowy, namiotowy ${ }^{40}$. W orzecznictwie sądowoadministracyjnym podnosi się nadto konieczność odróżnienia wymogów stawianych np. dachom budynków mieszkalnych od wymogów, które są związane z dachami budynków gospodarczych, jak przykładowo hali ${ }^{41}$.

Podnieść należy przy tym, że kilka budynków może być pokrytych jednym dachem. Jak wskazuje się bowiem w orzecznictwie sądowoadministracyjnym, posiadanie wspólnego dachu, ale bez wspólnego poddasza, oraz ściany łączącej obie części obiektu o odpowiedniej odporności ogniowej wpisuje się w jego samodzielność konstrukcyjną. W takim przypadku występują odrębne budynki, a to np. budynki jednorodzinne zrealizowane w formie zabudowy bliźniaczej².

\section{Podsumowanie}

Reasumując powyższe, wskazać należy, że obowiązkowemu ubezpieczeniu budynku wchodzącego w skład gospodarstwa rolnego od ognia i innych zdarzeń losowych podlegają wyłacznie - przy założeniu ziszczenia pozostałych przesłanek objęcia przedmiotowym ubezpieczeniem - obiekty trwale związane z gruntem, wydzielone z przestrzeni za pomoca przegród budowlanych oraz posiadające fundament i dach. Podkreślić należy przy tym, iż każdą z tych przesłanek trzeba weryfikować odrębnie, gdyż - jak to wskazano powyżej - może się zdarzyć, iż np. obiekt jest trwale związany z gruntem, ale jednocześnie nie posiada fundamentów. W toku ustaleń czynionych w tym zakresie trzeba mieć na uwadze również stale postępujący rozwój technik budowlanych i stosowanie nowych - wcześniej niewykorzystywanych - materiałów budowlanych. Pomocne w tym zakresie może być odwołanie się do orzecznictwa sądowego, które zostało obszernie przywołane w niniejszym tekście. Podkreślenia wymaga przy tym, że każdy obiekt budowlany trwale związany z gruntem, wydzielony z przestrzeni za pomoca przegród budowlanych oraz posiadający fundamenty i dach jest budynkiem, ale nie każdy taki obiekt jest budynkiem rolniczym. Nadto nie każdy budynek wchodzący w skład gospodarstwa rolnego podlega obowiązkowemu ubezpieczeniu od ognia i innych zdarzeń losowych.

Na marginesie powyższych rozważań należy zaznaczyć, iż przesłanką negatywną, której weryfikacja może budzić porównywalne watpliwości, jest - określone w art. 72 pkt 2 u.u.o. - wyłączenie spod zakresu obowiązkowego ubezpieczenia od ognia i innych zdarzeń losowych tych budynków w gospodarstwach rolnych, które zostały przeznaczone do rozbiórki na podstawie ostatecznych decyzji właściwych organów. Przepis ten - jak można przypuszczać - nie uwzględnia bowiem okoliczności, że legalna rozbiórka obiektu budowlanego nie w każdym przypadku wymaga wydania decyzji administracyjnej, przy czym to zagadnienie wymaga odrębnego opracowania.

40. Przepisy prawa nie formułują tych definicji, co oznacza konieczność posiłkowania się w tym zakresie opracowaniami z zakresu architektury i budownictwa (zob. np. A. Repelewicz, K. Regulska, Dachy: geometria i konstrukcja, Wydawnictwo Politechniki Częstochowskiej, Częstochowa 2004).

41. Zob. wyrok WSA w Krakowie z dnia 22 maja 2018 r., sygn. II SA/Kr 321/18, LEX nr 2507640.

42. Zob. wyrok NSA z dnia 5 lutego 2020 r., sygn. II OSK 2952/18, LEX nr 3072402. 


\section{Wykaz źródeł}

Asman T., Niewiadomski Z., [w:] Prawo budowlane. Komentarz, Niewiadomski Z. [red.], CH Beck, Warszawa 2011.

Despot-Mładanowicz A., [w:] Prawo budowlane. Komentarz, Plucińska-Filipowicz A., Wierzbowski M. [red.], Wolters Kluwer, Warszawa 2021, LEX/el.

Encyklopedia PWN, https://encyklopedia.pwn.pl/szukaj/dach.html [dostęp: ?.08.2021].

Encyklopedia PWN, https://encyklopedia.pwn.pl/szukaj/fundament.html [dostęp: 7.08.2021].

Gliniecki A., [w:] Prawo budowlane. Komentarz, Gliniecki A. [red.], LexisNexis, Warszawa 2014.

Kosicki A., [w:] Prawo budowlane. Komentarz, Plucińska-Filipowicz A., Wierzbowski M. [red.], Wolters Kluwer, Warszawa 2021, LEX/el.

Małysa-Sulińska K., Administracyjnoprawne aspekty inwestycji budowlanych, Wolters Kluwer, Warszawa 2012.

Małysa-Sulińska K., Przesłanki wydania zaświadczenia o samodzielności lokalu wykorzystywanego zgodnie z przeznaczeniem na cele inne niż mieszkalne, „Casus” 2020, nr 98/99.

Nawracała J., [w: Komentarz do ustawy o ubezpieczeniach obowiqzkowych, Ubezpieczeniowym Funduszu Gwarancyjnym i Polskim Biurze Ubezpieczycieli Komunikacyjnych, Tom I, Brodecki Z., Serwach M., Glicz M. [red.], Wolters Kluwer, Warszawa 2010, LEX/el.

Nawracała J., [w:] Kontrakty na rynku ubezpieczeń. Komentarz do przepisów i warunków ubezpieczeń, Fuchs D., Malinowska K., Maśniak D. [red.], Wolters Kluwer, Warszawa 2020.

Ostrowska A., [w:] Prawo budowlane. Komentarz, Gliniecki A. [red.], Lexis Nexis, Warszawa 2014. Repelewicz A., Regulska K., Dachy: geometria i konstrukcja, Wydawnictwo Politechniki Częstochowskiej, Częstochowa 2004.

Słownik języka polskiego, Wydawnictwa PWN Naukowe, Warszawa 2007.

\section{Classification of a building structure as an building being part of an agricultural farm within the meaning of the provisions on compulsory insurance of agricultural buildings}

Compulsory insurance of an agricultural building against fire and other random events applies to building structures which meet the criteria specified by the legislator. One of them is qualification of the structure in question as a building within the meaning of Art. 3[2] of the Act of 7 July 1994 - Construction Law. This involves verification of four features which every building should satisfy, namely: permanent attachment to the ground, separation from the space with building partitions, and having foundations and a roof. The development of building techniques, as well as investors' creativity, raises, more and more often, doubts as to the qualification of a building structure as a building within the meaning of the provisions of the said Act. The present article, with extensive reference to the case law of the administrative courts and the views of the doctrine, provides an in-depth analysis of all the indicated features of a building. The conditions for covering a building structure with obligatory insurance of an agricultural building against fire and other random events were also indicated. 
Keywords: compulsory insurance of an agricultural building against fire and other random events, agricultural building, reasons for covering a building structure with obligatory insurance of an agricultural building, building, features of a building.

DR HAB. KATARZYNA MAŁYSA-SULIŃSKA - profesor w Zakładzie Prawa Samorządu Terytorialnego, Uniwersytet Jagielloński.

e-mail: k.malysa-sulinska@uj.edu.pl

ORCID: 0000-0002-6406-8851 
